Journal of Applied Microbiology

October 2016, Volume 121, Issue 4, Pages 907-918

http://dx.doi.org/10.1111/jam.13179

http://archimer.ifremer.fr/doc/00334/44517/

(c) 2016 The Society for Applied Microbiology

\title{
Lactococcus piscium : a psychotrophic lactic acid bacterium with bioprotective or spoilage activity in food - a review
}

\author{
Saraoui Taous ${ }^{1,2,3}$, Leroi Francoise ${ }^{1,{ }^{*}}$, Björkroth Johanna ${ }^{4}$, Pilet Marie France ${ }^{2,3}$
}

${ }^{1}$ Ifremer, Laboratoire Ecosystèmes Microbiens et Molécules Marines pour les Biotechnologies (EM3

B),; Rue de l'lle d'Yeu 44311 Nantes Cedex 03, France

2 LUNAM Université, Oniris; UMR1014 Secalim, Site de la Chantrerie; F-44307 Nantes, France

3 INRA; F-44307 Nantes ,France

${ }^{4}$ University of Helsinki; Department of Food Hygiene and Environmental Health; Helsinki ,Finland

* Corresponding author : Françoise Leroi, tel.: +33240374172; fax: +33240374071;

email address : Francoise.Leroi@ifremer.fr

\begin{abstract}
:
The genus Lactococcus comprises twelve species, some known for decades and others more recently described. Lactococcus piscium, isolated in 1990 from rainbow trout, is a psychrotrophic lactic acid bacterium ( $L A B)$, probably disregarded because most of the strains are unable to grow at $30^{\circ} \mathrm{C}$. During the last 10 years, this species has been isolated from a large variety of food: meat, seafood and vegetables, mostly packed under vacuum (VP) or modified atmosphere (MAP) and stored at chilled temperature. Recently, culture-independent techniques used for characterization of microbial ecosystems have highlighted the importance of $L$. piscium in food. Its role in food spoilage varies according to the strain and the food matrix. However, most studies have indicated that $L$. piscium spoils meat, whereas it does not degrade the sensory properties of seafood. L. piscium strains have a large antimicrobial spectrum, including Gram-positive and negative bacteria. In various seafood, some strains have a protective effect against spoilage and can extend the sensory shelf-life of the products. They can also inhibit the growth of Listeria monocytogenes, by a cell-to-cell contact-dependent. This article reviews the physiological and genomic characteristics of $L$. piscium and discusses its spoilage or protective activities in food.
\end{abstract}

Keywords : lactic acid bacteria, biopreservation, spoilage, meat, seafood, cold adaptation. 
Introduction

Lactic acid bacteria (LAB) constitute a heterogeneous group of Gram-positive bacteria, primarily nonsporulating, anaero-aerotolerant, and producing lactic acid as the principal end metabolite from carbohydrate fermentation. LAB can dominate the natural microbiota of many fermented foods where they play a key role in the development of the sensory properties (flavor and texture) and safety. In an appropriate environment, $\mathrm{LAB}$ can also colonize non-fermented products from plant or animal origin (Stiles and Holzapfel, 1997). Among LAB, the genus Lactococcus, and 
particularly Lactococcus lactis, has been extensively studied, as some species are of major economic importance for the food bio-transformation industry (Stiles, 1996). The species L. piscium was isolated and characterized for the first time from diseased rainbow trout in 1990 (Williams et al., 1990). However, during the last 10 years its presence has been reported in various food and this species is gaining the interest of scientists. L. piscium is described either as a bioprotective or a spoilage microorganism depending on the strains and food matrix in concern.

This review deals with the characteristics of this species and its importance in food.

\section{Taxonomy}

Although many bacterial species produce lactic acid, the LAB group is restricted to fourteen genera, five of them constituting the core group (Lactobacillus, Lactococcus, Leuconostoc, Pediococcus and Streptococcus). The genus Lactococcus belongs to the phylum Firmicutes, Class Bacilli, Order Lactobacillales and Family Streptococcaceae (Samarzija et al. 2001). This genus is known for the ability to produce L-lactic acid from glucose. Lactococcus was proposed by Schleifer et al. (1985) to reclassify some species of the genus Streptococcus formerly included in the N-Lancefield group (lactic streptococci), according to DNA-DNA hybridization, 16S rRNA gene sequencing and basic physiological studies. Five species were initially described : L. lactis, L. piscium, Lactococcus garvieae, Lactococcus raffinolactis and Lactococcus plantarum. Recently, six new species have been described: Lactococcus chungangensis (Cho et al., 2008), Lactococcus fujiensis (Cai et al., 2011), Lactococcus taiwanensis (Chen et al., 2013), Lactococcus formosensis (Chen et al., 2014), Lactococcus hircilactis and Lactococcus laudensis (Meucci et al., 2015).

Phylogenetic analysis performed by the authors has revealed that the genus Lactococcus formed two significantly distinct phylogenetic groups (bootstrap $\geq 98 \%$ ) (Figure 1). The four subspecies of $L$. lactis (subsp. lactis, cremoris, tractae and hordniae), as well as L. taiwanensis, L. hircilactis, L. fujiensis, L. garvieae and L. formosensis formed the first group whereas L. laudensis, L. raffinolactis, 
L. chungangensis, L. plantarum and L. piscium grouped close related together. Interestingly, this phylogenetic analysis indicated that $L$. piscium clustered with $L$. plantarum supported by a bootstrap value of $92 \%$ and $99 \%$ sequence similarity. This result confirmed those obtained by Rahkila et al. (2012) who obtained two distinct phylogenetic groups of Lactococcus using two different analysis (i) 16S rRNA gene sequences of twenty-two LAB strains and (ii) partial sequences of the housekeeping genes rpoA and pheS of seventy-one LAB. In the same study, they showed that numerical analyses of EcoRI and ClaI ribopatterns and phylogenetic sequence analyses of rpoA and pheS genes were reliable tools in species level identification of meat lactococci. In addition, the pangenome tree made on thirty lactococci genome revealed 3 major clades: (i) species of environmental or animal origin $(L$. piscium, L. raffinolactis, L. chungangensis and L. garvieae); (ii) L. lactis subsp. lactis strains and (iii) L. lactis subsp. cremoris strains (Andreevskaya et al., 2015).

Some strains, mainly L. lactis, are widely applied in industrial processes as starter cultures (Kelly et al., 2010), probiotics (Daniel et al., 2009) and protective cultures (Sarika et al., 2012). L. lactis is generally recognized as safe (GRAS) by the US FDA and considered by the EFSA to be suitable for the Qualified Presumption of Safety (QPS) approach to safety (EFSA, 2011). It has been used for decades by the dairy industry, and has thus been extensively studied as a model microorganism. Biochemical, physiological, and genetic aspects of L. lactis are widely described in the literature (for a review see Von Wright, 2012; Cavanagh et al., 2015). Over the years, interest has grown in the other four species initially described in the genus: L. garvieae, L. raffinolactis, L. plantarum and L. piscium (Boucher et al., 2003; Alomar et al., 2008; Matamoros et al., 2009a; Rahkila et al., 2012).

\section{Habitat}

L. piscium was described for the first time by Williams et al. (1990) in diseased rainbow trout. Its direct involvement in the disease has never been evidenced and, to the best of our knowledge, $L$. piscium has never again been isolated or identified by culture-independent techniques in the fish intestine microbiota. However, in marine farmed fish, other Lactococcus species have been shown to 
be involved in epizoothics, such as L. garvieae responsible for septicemias, opthalmias and hemorrhages (Eldar et al., 1996; Vendrell et al., 2006) and L. raffinolactis, which has been identified as a fish commensal and also an opportunistic pathogen (Michel et al., 2007).

During the last 10 years, L. piscium has been isolated in a variety of chilled, modified atmosphere (MAP) and vacuum packed (VP) food (Table 1), including beef meat (Sakala et al., 2002a; Ferrocino et al., 2015; Jääskelänen et al., 2016), MAP marinated broiler meat leg (Björkroth et al., 2005), MAP skinned and boned broiler products (Vihavainen et al., 2007), raw salmon under MAP (Matamoros et al., 2009a; Macé et al., 2012), VP and MAP pork (Jiang et al., 2010; Rahkila et al., 2012), fermented turkey sausage (Kesmen et al., 2012), raw and cooked Belgium meat, tartar steak and ready-to-eat minimally processed vegetable salads (Delhalle et al., 2016; Pothakos et al., 2014a,b).

More recently, the use of culture independent techniques has revealed the presence of L. piscium in other products, although strains have not always been isolated. Chaillou et al. (2015a) conducted 16S rRNA gene pyrosequencing on 160 samples of fresh and spoiled foods to compare the bacterial communities associated with four meat products (ground veal and beef, diced bacon and poultry sausage) and four seafood products (salmon and cod fillet, cold-smoked-salmon (CSS) and cooked shrimp). L. piscium was the dominant species in ground veal and ground beef stored at 4 and $8^{\circ} \mathrm{C}$ under MAP $\left(70 \% \mathrm{O}_{2}, 30 \% \mathrm{CO}_{2}\right)$. L. piscium was also in the top five species of the microbiota of MAP salmon fillets $\left(50 \% \mathrm{O}_{2}, 50 \% \mathrm{CO}_{2}\right)$ and in the top twelve in CSS (Chaillou et al., 2015b).

The presence of L. piscium has also been reported in dairy products such as raw milk, using a novel multiplex PCR (Odamaki et al., 2011), and cheese, using 16S rRNA library sequencing (Carraro et al., 2011), as well as in human feces by rRNA-Targeted Reverse-PCR (Kubota et al., 2010).

\section{Genomic characteristics of Lactococcus piscium}

The complete genomes of numerous Lactococcus species, have been sequenced e.g. L. lactis (Bolotin et al., 2001; Makarova et al., 2006), L. raffinolactis (Meslier et al., 2012), L. garvieae (Morita et al., 2011), L. piscium (Marché et al., 2014; Andreevskaya et al., 2015), L. fujiensis 
(http://www.ncbi.nlm.nih.gov) and L. chungangensis (https://www.patricbrc.org) (Table 2). Those species have genomes ranging between 1950 to $2641 \mathrm{kbp}$ and contained 1947 to 2476 coding DNA

Sequences (CDS). This indicates variability in genome size between species of Lactococcus up to 750 kbp. Genome-based analysis performed by Passerini et al. (2010) revealed that there are a genome size variability up to $600 \mathrm{kbp}$ even within L. lactis subsp. lactis strains.

Concerning L. piscium, two different strains have been sequenced: L. piscium MKFS47, a spoiling strain of meat isolated from MAP broiler fillet strips (Andreevskaya et al., 2015) and L. piscium CNCM I-4031 (also named L. piscium EU2241), a bioprotective strain in seafood isolated from MAP raw salmon (Marché et al., 2014). The L. piscium MKFS47 genome size is 2.5 Mb and GC\% content is $38.79 \%$. It contains one chromosome with 2394138 bp (2289 CDS) and two plasmids with $55671 \mathrm{bp}(66 \mathrm{CDS})$ and $53257 \mathrm{bp}$ (64 CDS). Annotated genomic nucleotide sequences are accessible through the European Nucleotide Archive (http://www.ebi.ac.uk/ena) under accession numbers LN774769-LN77477. The functions of deduced CDS-encoded proteins have been attributed to (i) proteins involved in primary and secondary metabolism and transport; (ii) transcription, translation, ribosomal structure and DNA replication and repair; (iii) cell division, envelope biogenesis and cell motility; (iv) metabolism, energy production and conversion; (v) signal transduction mechanism and (vi) proteins of unknown function (Andreevskaya et al., 2015). The L. piscium CNCM I-4031 genome size is $\sim 2.26 \mathrm{Mb}$ with $2239 \mathrm{CDS}$ and GC\% content is $39 \%$. It contains one chromosome and one plasmid of $20 \mathrm{~Kb}$. Annotated genomic nucleotide sequences are not accessible yet. A major part of its CDS-encoded proteins are classified as proteins of unknown function, $24 \%$ as enzymes, $20 \%$ represent transporters, regulators and factors, and 16\% fall under components of cell processes and miscellaneous categories (Marché et al., 2014).

\section{Physiological characteristics of Lactococcus piscium}

L. piscium is a facultative anaerobic, Gram-positive, catalase- and oxidase-negative and nonmotile cocci from 0.5 to $1 \mu \mathrm{m}$ in diameter. Cells are spherical or ovoid and appear individually, in pairs or in short chains. A scanning electron microscopy picture is presented in Figure 2. Cai et al. 
(2011) and Sakala et al. (2002b) showed that L. piscium was not able to grow at $30 \mathrm{~g} \mathrm{l}^{-1} \mathrm{NaCl}$ or higher. Leroi et al. (2012) later demonstrated that the $\mathrm{NaCl}_{\max }$ growth of L. piscium CNCM I-4031 was $23 \mathrm{~g}^{-1} \mathrm{l}^{-1}$. The optimal $\mathrm{pH}$ for growth was neutral and L. piscium could not grow at $\mathrm{pH}$ below to 4.8 (Cai et al., 2011; Leroi et al., 2012; Meucci et al., 2015).

Biochemical analysis, metabolic profiling and the genome analysis (Williams et al., 1990; Sakala et al., 2002b; Andreevskaya et al., 2015; Saraoui et al., 2016) revealed that L. piscium is a homofermentative bacterium that can ferment many carbon sources. Although only few L. piscium strains have been tested according to the literature, authors have shown that the following carbohydrates are fermented: glucose, fructose, lactose, galactose, gluconate, gentiobiose, mannose, maltose, melobiose, trehalose, arbutin, L-arabinose, $N$-acetylglucosamine, salicin, and D-raffinose. In addition, some strains can use saccharose, D-turanose, D-xylose, melezitose, $\alpha$-methyl-D-glucoside, $\alpha$-methyl-Dmannoside, mannitol and amygdalin (Williams et al., 1990; Sakala et al., 2002b; Fall, 2011; Chen et al., 2013). The fermentation of ribose is variable and strain-dependent (Sakala et al., 2002b; Andreevskaya et al., 2015). Sequencing and annotation of the genome of L. piscium MKFS47 by Andreevskaya et al. (2015) has shown that many catabolic pathways are predicted, including the degradation of monosaccharides (glucose, fructose, mannose, mannitol and xylose) and disaccharides (saccharose, maltose, lactose, trehalose and cellobiose). These authors also demonstrated that $L$ piscium MKFS47 can grow on glycerol as a unique carbon source with a growth rate comparable to that obtained on glucose.

A metabolic profile of $L$. piscium strain CNCM I-4031 in a synthetic medium called "modified shrimp medium" (MSMA) containing glucose and other components showed that this strain catabolizes cysteine, histidine and glycine and, in lesser quantities, isoleucine, lysine and leucine, as well as the nucleic bases (adenine, guanine and uracil) and a vitamin (riboflavin) (Saraoui et al., 2016). In addition to these catabolic capacities, L. piscium harbors genes for the biosynthesis of all amino acids, except phenylanine, of purine/pyrimidine and also several cofactors/vitamins, such as riboflavin, folate, CoA, NAD, lipoate and polyprenyls (Andreevskaya et al., 2015). The L. piscium strains are able to hydrolyze aesculin but not arginine and they have no urease activities. Starch hydrolysis is 
slow and weak while $\mathrm{H}_{2} \mathrm{~S}$ is not produced (Williams et al., 1990). Acetic acid production is straindependent. In fact, the strain CNCM I-4031 does not produce acetic acid (Fall, 2011) whereas this metabolite is produced by the strains R-46592 and MKFS47 (Pothakos et al., 2014c; Andreevskaya et al., 2015).

\section{Cold-adaptation of Lactococcus piscium}

The adaptation of LAB to different environmental conditions makes them of great importance in the food industry. For example, these bacteria can survive different environmental stresses caused by various steps in industrial processes, such as low temperature, high salt concentration, presence of preservative agents such as organic acids, and high $\mathrm{CO}_{2}$ concentrations (Tsakalidou and Papadimitriou, 2011). L. piscium has long been disregarded in food, probably because the enumeration temperature commonly used for $\mathrm{LAB}$ enumeration has been $30^{\circ} \mathrm{C}$. Since lower temperatures have been recently tested more frequently, L. piscium has been isolated in various chilled VP or MAP meat and seafood. Several strains of L. piscium were isolated on Elliker agar plates incubated at $8^{\circ} \mathrm{C}$ (Matamoros et al., 2009a). L. piscium is a psychrotrophic species, able to grow at $0^{\circ} \mathrm{C}$ with an optimum growth temperature at $24-26^{\circ} \mathrm{C}$ and a maximum growth temperature below $27-29^{\circ} \mathrm{C}$, which is not common among LAB (Matamoros et al., 2009a; Leroi et al., 2012). Growth at $30^{\circ} \mathrm{C}$ is weak and variable among the strains. Another L. piscium isolated from raw salmon failed to grow at $30^{\circ} \mathrm{C}$ (Leroi et al., 2012) whereas L. piscium type strain grew at $30^{\circ} \mathrm{C}$ but not at $35^{\circ} \mathrm{C}$ (Williams et al., 1990). Growth at $5^{\circ} \mathrm{C}$ was observed for all of the 20 strains tested (isolated from fresh VP beef) and development was weak and variable at $30^{\circ} \mathrm{C}$ (Sakala et al., 2002b). Despite the absence of growth at $37^{\circ} \mathrm{C}$ (Williams et al., 1990; Sakala et al., 2002b; Leroi et al., 2012; Andreevskaya et al., 2015), it is noteworthy that L. piscium has been isolated from human intestine (Kubota et al., 2010). All the other Lactococcus species are mesophilic microorganisms with an optimum growth temperature around $30^{\circ} \mathrm{C}$ (Cavanagh et al., 2015; Meucci et al., 2015). L. lactis, $L$.

This article is protected by copyright. All rights reserved. 
garvieae, L. plantarum and L. raffinolactis continued to grow at $35^{\circ} \mathrm{C}$ (Leroi et al., 2012). This characteristic may help to differentiate L. piscium from other Lactococcus species.

The unusual temperature-growth profile among Lactococci suggests that L. piscium is adapted to cold temperatures. Garnier et al. (2010) showed that the growth kinetics of L. piscium CNCM I4031 at its optimum growth temperature $\left(26^{\circ} \mathrm{C}\right)$ and after a cold-shock $\left(0\right.$ or $5^{\circ} \mathrm{C}$ for 1 to $\left.2 \mathrm{~h}\right)$ were similar (same growth rate and no lag phase). Additionally, no lag phase was observed when cultures were carried out at $5^{\circ} \mathrm{C}$, after a pre-culture at $26^{\circ} \mathrm{C}$, contrary to most Lactococcus species and other psychrotrophic LAB (Hamasaki et al., 2003). The specific result suggested that the proteins involved in the cold-shock response are constitutively produced. This is supported by the fact that the gene coding for the major cold-shock protein (CspE protein) was present in the L. piscium genome but its expression has been shown not to be regulated by cold-shock (Matamoros, 2008; Garnier et al., 2010). In other psychrotrophic bacteria, such as Pseudomonas fragi and Bacillus subtilis, the Csp protein was up-regulated in response to cold-shock and did not persist after the stress (Michel et al., 1997;

Graumann and Marahiel, 1998). The comparison of proteome profiles of L. piscium at $26^{\circ} \mathrm{C}$ and after cold-adaptation $\left(5^{\circ} \mathrm{C}\right)$ showed that the production of proteins involved in general and oxidative stress responses and in fatty acid and energetic metabolism was enhanced in cold conditions (Garnier et al., 2010). This can be explained by the fact that the Csp proteins play a significant role in many cellular processes such as general stress, cellular growth, nutrient stress and the stationary phase (Graumann and Marahiel, 1998).

Cold-adaptation constitutes an important advantage for bacterial competition in chilled food, especially against spoilage and pathogenic psychrotrophs, providing a promising perspective for food preservation.

\section{Role of Lactococcus piscium in food spoilage}

The quality of food can be determined by different sensory parameters such as appearance, odor, flavor and texture. The deterioration of freshness occurs progressively during storage due to internal reactions between food components, reactions of the components with water and air and, 
mainly, the growth and metabolic activity of uncontrolled microorganisms (Lupien, 1997). The products become spoiled and unfit for human consumption and therefore have to be discarded. This process leads to significant economic losses and is a major problem for the food industry. Food waste at the consumer level in industrialized countries (222 million tons) is almost as high as the total net food production in sub-Saharan Africa (230 million tons) (Gustavsson et al., 2011). As a result, some strategies have already been adopted to prevent or delay this degradation, such as storage at chilled temperature, VP, MAP or addition of preservative agents (Borch et al., 1996). The microbial selection caused by these technologies gradually reduces the number of species present at the time of spoilage. As an example, in 160 samples of various meat and seafood products, the initial number of operational taxonomic units drastically decreased during MAP and VP storage. LAB and Brochothrix became dominant at the time of spoilage in meat, and LAB and Photobacterium in seafood (Chaillou et al., 2015a).

L. piscium has recently been shown to be one of the predominating species in chilled packed food, but its spoilage capability has to be demonstrated by challenge tests. In fact, it has clearly been established that in a food microbial ecosystem, only some microorganisms are involved in spoilage. This led to the concept of the specific spoilage organisms (Dalgaard, 1995; Leroi et al., 2015). The spoilage effect of $L$. piscium has been studied in different food matrixes by inoculating different strains into sterile or low contaminated food matrixes (Table 1). In sterile raw salmon fillets stored at $8^{\circ} \mathrm{C}$ under MAP $\left(50 \% \mathrm{CO}_{2}-50 \% \mathrm{~N}_{2}\right)$, the concentration of $L$. piscium increased from 3 to $9 \mathrm{Log}$ $\left(\mathrm{CFU} \mathrm{g} \mathrm{g}^{-1}\right)$ in 12 days and the samples were described as not spoiled by $56 \%$ of trained judges and lightly spoiled by $44 \%$. The weak odors associated were buttery and/or fatty fish-like (Macé et al., 2013). This low spoilage effect and characteristic off-odors are in accordance with other studies performed with different strains of L. piscium on CSS or cooked shrimp (Matamoros et al., 2009b; Fall et al., 2012; Leroi et al., 2015). In pork, L. piscium has a lightly spoiling effect (Rahkila et al., 2012). Two strains of L. piscium were inoculated on pork meat packed under MA conditions $\left(71 \% \mathrm{O}_{2}\right.$ $-22 \% \mathrm{CO}_{2}-7 \% \mathrm{~N}_{2}$ ) and stored at $6^{\circ} \mathrm{C}$. The concentration of both strains reached approximately 8 $\log \left(\mathrm{CFU} \mathrm{g}^{-1}\right)$. The products inoculated were characterized by buttery and sour odors after 2 weeks of 
storage. The buttery off-odor was related to diacetyl/acetoin formation, which is frequently associated with the spoilage of food (Vihavainen et al., 2007; Jääskeläinen et al., 2015). After $48 \mathrm{~h}$ in modified Man-Rogosa-Sharpe (MRS) medium without acetate and with 2\% glucose, a final concentration of diacetyl and acetoin produced by L. piscium reached $8.5 \mathrm{mM}$ (Andreevskaya et al., 2015). In MAP $\left(70 \% \mathrm{O}_{2}-30 \% \mathrm{CO}_{2}\right.$ ) ground veal at $8^{\circ} \mathrm{C}$, L. piscium was shown to modify the color greatly, from red to gray (Denis et al., 2014). In ground beef under the same conditions, L. piscium acidified the meat (lowering 0.45 units the $\mathrm{pH}$ ) and deteriorated the color, which became gray/green and released a strong rancid odor (personal communication from Souad Christeans, 2014).

The spoilage effect of three strains of L. piscium isolated from beef, pork and sweet peppers was studied in bell pepper simulation medium under three different conditions of gas composition: (i) $100 \% \mathrm{~N}_{2}$; (ii) air: $21 \% \mathrm{O}_{2}$ and $79 \% \mathrm{~N}_{2}$; (iii) $\mathrm{MAP}_{1}: 30 \% \mathrm{CO}_{2}$ and $70 \% \mathrm{~N}_{2}$ and (iv) $\mathrm{MAP}_{2}: 50 \% \mathrm{O}_{2}$ and $50 \% \mathrm{CO}_{2}$ (Pothakos et al., 2014a). In the first three conditions, all strains reached about 7-9 Log (CFU $\mathrm{g}^{-1}$ ) with some differences in growth speed between the strains. For the $\mathrm{MAP}_{2}$ condition, only the strain isolated from beef was able to grow and reached about $\left.8 \mathrm{Log}(\mathrm{CFU} \mathrm{g})^{-1}\right)$ at the end of storage, suggesting that the combination of high $\mathrm{O}_{2}$ and $\mathrm{CO}_{2}$ concentration had a significant inhibitory effect on L. piscium. Only one strain, showing the best growth in all packing conditions, had a significant spoiling effect. This effect was correlated to the production of some metabolites that are involved in spoilage, such as ethanol after 7 days in $100 \% \mathrm{~N}_{2}$ and $\mathrm{MAP}_{1}$ conditions, acetic acid after 7 days in air and 2,3 butanedione (diacetyl) after 13 days in the $\mathrm{MAP}_{2}$ condition (Pothakos et al., 2014c). These results are supported by the presence in the L. piscium genome of four predicted pathways for pyruvate utilization: acetoin/diacetyl, pyruvate dehydrogenase, L-lactate dehydrogenase and pyruvateformate lyase pathways (Andreevskaya et al., 2015). Many significant spoilage substances, such as acetoin/diacetyl and acetate, are produced by these pathways.

This article is protected by copyright. All rights reserved. 


\section{Protective effect of Lactococcus piscium}

During the recent years, consumers have shown a great interest in ready-to-eat, minimally processed and fresh-tasting food. In this context, chilled storage and modification of the gaseous environment of food have been developed and have become important and acceptable methods for food preservation (Cortesi et al., 2009). However, the drawback of these technologies is that the safety and quality of the product has to be maintained throughout a significantly-increased storage time (Ross et al., 2002). The physico-chemical characteristics of these products allow the development of a wide range of undesirable microorganisms, like pathogenic and spoilage bacteria. Biopreservation, which consists of inoculating food with selected protective bacterial strains that can inhibit undesirable components of the microbiota, is an increasing practice in the food industry. Many studies have demonstrated the interest of LAB such as Carnobacterium, Lactobacillus, Lactococcus and Leuconostoc for this purpose (for a review, see Rouse and van Sinderen, 2008; Lacroix, 2010; Ghanbari et al., 2013). In this context, the role of L. piscium has been extensively studied in recent years, mainly in seafood.

The positive effect of L. piscium on the sensory quality of VP cooked and peeled tropical shrimp was demonstrated for the first time by Matamoros et al. (2009a). After 28 days of storage at $8^{\circ} \mathrm{C}$, the shrimps inoculated with L. piscium CNCM I-4031 and EU2229 were not spoiled whereas the control released very strong off-odors described as "cheese and feet" by sensory panel. These authors also showed that the strain CNCM I-4031 improved the sensory quality of VP CSS. However, the protective effect seems to be strain-dependent as L. piscium EU2229 had no effect on the sensory quality of the same batch of VP CSS. In another set of experiments, Leroi et al. (2015) confirmed the beneficial effect of $L$. piscium CNCM I-4031 in one batch of naturally contaminated CSS out of two batches tested, from different smokehouses, suggesting that the protective effect of this strain may vary according to its interaction with the spoiling microorganisms.

This article is protected by copyright. All rights reserved. 


\section{Antimicrobial activity of Lactococcus piscium}

The antimicrobial activity of $L$. piscium has not been commonly tested. The inhibitory capability of L. piscium CNCM I-4031 and EU2229 against Gram-positive and -negative spoilage bacteria relevant in meat and seafood was tested using a diffusion test on Petri dishes (Matamoros et al., 2009a; Fall et al., 2010a). These strains had a large activity spectrum towards strains of Brochothrix, Lactobacillus, Carnobacterium, Vagococcus, Enterococcus, Psychrobacter, Shewanella, Pseudomonas and Serratia (Table 3). The inhibitory activity was confirmed on a seafood matrix for B. thermosphacta, which is considered a major spoilage bacteria in VP and MAP meat and seafood. $L$. piscium CNCM I-4031 inhibited the growth of B. thermosphacta by 3-4 Log (CFU. $\left.\mathrm{g}^{-1}\right)$ in cooked and peeled shrimps (Fall et al., 2010a; 2012) and totally stopped its growth in CSS (Leroi et al., 2015). The inhibition of $B$. thermosphacta had been reported previously with some LAB such as Lactobacillus spp. in meat (Castellano and Vignolo, 2006; Russo et al., 2006) but not with some other such as Carnobacterium spp. in MAP shrimp (Laursen et al., 2006).

L. piscium is also able to inhibit the growth of pathogens or opportunistic pathogens such as E. coli, Salmonella, Staphylococcus aureus, Clostridium sporogenes and L. monocytogenes (Table 3). (Matamoros et al., 2009a; Fall et al., 2010b). The antagonist activity against L. monocytogenes is particularly relevant in meat and seafood since this pathogen is frequently isolated from these foodstuffs (Gambarin et al., 2012; Lomonaco et al., 2015). Its anti-listeria activity has been confirmed in VP and MAP cooked and peeled shrimp by Matamoros et al. (2009a) and Fall et al. (2010b).

The antimicrobial activities of LAB against food spoiling bacteria is generally associated with the production of (i) antimicrobial peptides, such as bacteriocins (Stiles, 1996; Brillet et al., 2005) or reuterin (El-Ziney et al., 1999); (ii) organic acids, such as acetic and lactic acid (Wong and Chen, 1988); (iii) hydrogen peroxide (Alomar et al., 2008) and with (iv) nutrient competition (Nilsson et al., 2005). In the case of $L$. piscium CNCM I-4031, the mechanism involved in its antimicrobial properties has not yet to be elucidated, remaining a challenge for researchers. Different tests performed on various culture media and food matrix demonstrated that the inhibition of $L$.

This article is protected by copyright. All rights reserved. 
monocytogenes was not due to the production of extracellular antimicrobial compounds (Matamoros et al., 2009a; Saraoui et al., 2016). The strain MKFS47 has not been studied for its antimicrobial activity but its genome analysis has revealed the presence of some genes that could be involved in putative antimicrobial factors. This strain contains three gene clusters involved in the biosynthesis of putative bacteriocins. In addition, various enzymes putatively involved in $\mathrm{H}_{2} \mathrm{O}_{2}$ biosynthesis have been identified. However, these different gene clusters may not be activated in all environmental conditions. As an example, $\mathrm{H}_{2} \mathrm{O}_{2}$ was produced from glycerol under aerobic conditions but not from glucose under aerobic and anaerobic conditions (Andreevskaya et al., 2015). Nutrient depletion has also been reported to explain the competition between microbial populations (Hibbing et al., 2010). For instance, Juillard et al. (1998) showed a nutrient competition for non-protein nitrogenous substrates in milk between Lactococcus and Leuconostoc strains. Nilsson et al. (2005) showed that the inhibition of L. monocytogenes by Carnobacterium piscicola was due to the competition for glucose. Saraoui et al. (2016) demonstrated that the inhibition of L. monocytogenes by L. piscium was not due to nutrient competition (various compounds tested). The inhibition occurred in co-culture but not in a diffusion chamber, where bacteria were separated by a filter membrane, nor in medium pre-fermented by $L$. piscium. These results indicate that the inhibition of $L$. monocytogenes by $L$. piscium is through a non-uncharacterized, cell-to-cell contact-dependent that are never been reported in LAB.

\section{Conclusion}

L. piscium is gaining the interest of researchers because it is increasingly isolated from various meat, seafood, vegetable and dairy products. It is the only psychrotrophic species in the genus Lactococcus and thus can play an important role in minimally processed products stored at chilled temperatures. The spoiling activity depends on the strain, the food matrix and storage conditions. In most cases, L. piscium does not spoil seafood and even has a protective effect, whereas it strongly alters the quality of meat, with discoloration, acidification and the production of buttery, rancid and sour off-odors. In seafood, some strains can prevent the spoilage and extend the sensory shelf-life. 
This has been attributed to the inhibition of $B$. thermosphacta, a major spoilage bacterium in refrigerated packed meat and fish. However, other mechanisms are probably involved, as a protective effect observed in one batch of CSS could not be attributed to the reduction of this species, nor other bacteria enumerated by classic and culture-independent methods (Leroi et al., 2015). An anti-listerial effect of L. piscium has also been observed and attributed to cell-to-cell contact, although the mechanism still remains unknown. This inhibitory mechanism has never been described in other LAB. Comparative genomic and transcriptomic analyses may help to answer many questions concerning the spoiling and protective potential of L. piscium.

\section{Acknowledgments}

Taous Saraoui was the recipient of a Ph.D. fellowship from the French Ministry of Higher Education and Research. The authors thank Dr Delphine Passerini for assistance with phylogenetic analysis and for her advices.

\section{Conflict of interest}

There is no conflict of interest.

\section{Reference}

Alomar, J., Loubiere, P., Delbes, C., Nouaille, S. and Montel, M.C. (2008) Effect of Lactococcus garvieae, Lactococcus lactis and Enterococcus faecalis on the behaviour of Staphylococcus aureus in microfiltered milk. Food Microbiol 25, 502-508.

Andreevskaya, M., Johansson, P., Laine, P., Smolander, O.-P., Sonck, M., Rahkila, R., Jääskeläinen, E., Paulin, L., Auvinen, P. and Björkroth, J. (2015) Genome sequence and transcriptome 
analysis of meat spoilage lactic acid bacterium Lactococcus piscium MKFS47.App Environ Microbiol 81, 3800-3811.

Björkroth, J., Ristiniemi, M., Vandamme, P. and Korkeala, H. (2005) Enterococcus species dominating in fresh modified-atmosphere-packaged, marinated broiler legs are overgrown by Carnobacterium and Lactobacillus species during storage at $6{ }^{\circ} \mathrm{C}$. Int J Food Microbiol 97 , 267-276.

Bolotin, A., Wincker, P., Mauger, S., Jaillon, O., Malarme, K., Weissenbach, J., Ehrlich, S.D. and Sorokin, A. (2001) The complete genome sequence of the lactic acid bacterium Lactococcus lactis ssp. lactis IL1403. Genome Res 11, 731-753.

Borch, E., Kant-Muermans, M.L. and Blixt, Y. (1996) Bacterial spoilage of meat and cured meat products.Int J Food Microbiol 33, 103-120.

Boucher, I., Vadeboncoeur, C. and Moineau, S. (2003) Characterization of genes involved in the metabolism of $\alpha$-Galactosides by Lactococcus raffinolactis. App Environ Microbiol 69, 40494056.

Brillet, A., Pilet, M.-F., Prevost, H., Cardinal, M. and Leroi, F. (2005) Effect of inoculation of Carnobacterium divergens V41, a biopreservative strain against Listeria monocytogenes risk, on the microbiological, chemical and sensory quality of cold-smoked salmon. Int J Food Microbiol 104, 309-324.

Cai, Y., Yang, J., Pang, H. and Kitahara, M. (2011) Lactococcus fujiensis sp. nov., a lactic acid bacterium isolated from vegetable matter.Int J Syst Evol Microbiol 61, 1590-1594.

Carraro, L., Maifreni, M., Bartolomeoli, I., Martino, M.E., Novelli, E., Frigo, F., Marino, M. and Cardazzo, B. (2011) Comparison of culture-dependent and-independent methods for bacterial community monitoring during Montasio cheese manufacturing. Res Microbiol 162, 231-239.

Castellano, P. and Vignolo, G. (2006) Inhibition of Listeria innocua and Brochothrix thermosphacta in vacuum-packaged meat by addition of bacteriocinogenic Lactobacillus curvatus CRL705 and its bacteriocins. Lett App Microbiol 43, 194-199.

Cavanagh, D., Fitzgerald, G.F. and McAuliffe, O. (2015) From field to fermentation: The origins of Lactococcus lactis and its domestication to the dairy environment. Food Microbiol 47, 45-61.

This article is protected by copyright. All rights reserved. 
Chaillou, S., Chaulot-Talmon, A., Caekebeke, H., Cardinal, M., Christieans, S., Denis, C., Hélène Desmonts, M., Dousset, X., Feurer, C., Hamon, E., Joffraud, J.-J., La Carbona, S., Leroi, F., Leroy, S., Lorre, S., Macé, S., Pilet, M.-F., Prévost, H., Rivollier, M., Roux, D., Talon, R., Zagorec, M. and Champomier-Vergès, M.-C. (2015a) Origin and ecological selection of core and food-specific bacterial communities associated with meat and seafood spoilage. The ISME J 9, 1105-1118.

Chaillou, S., Chaulot-Talmon, A., Caekebeke, H., Cardinal, M., Christieans, S., Denis, C., desmonts, M.H., Dousset, X., Feurer, C., Hamon, E., Joffraud, J.-J., La Carbona, S., Leroi, F., Leroy, S., Lorre, S., Macé, S., Pilet, M.F., Prévost, H., Rivollier, M., Roux, D., Talon, R., Zagorec, M. and Champomier-Vergès, M.-C. (2015b) supporting-files-isme2015-202-v5.0. http://www.nature.com/ismej/journal/v9/n5/suppinfo/ismej2014202s1.html?url=/ismej/journal /v9/n5/full/ismej2014202a.html

Chen, Y., Otoguro, M., Lin, Y., Pan, S., Ji, S., Yu, C., Liou, M., Chang, Y., Wu, H. and Yanagida, F. (2014) Lactococcus formosensis sp. nov., a lactic acid bacterium isolated from yan-tsai-shin (fermented broccoli stems). Int J Syst Evol Microbiol 64, 146-151.

Chen, Y. -s., Chang, C. -h., Pan, S. -f., Wang, L. -t., Chang, Y. -c., Wu, H. -c. and Yanagida, F. (2013) Lactococcus taiwanensis sp. nov., a lactic acid bacterium isolated from fresh cummingcordia.Int J Syst Evol Microbiol 63, 2405-2409.

Cho, S.-L., Nam, S.-W., Yoon, J.-H., Lee, J.-S., Sukhoom, A. and Kim, W. (2008) Lactococcus chungangensis sp. nov., a lactic acid bacterium isolated from activated sludge foam. Int J Syst Evol Microbiol 58, 1844-1849.

Cortesi, M.L., Panebianco, A., Giuffrida, A., Anastasio, A. (2009) Innovations in seafood preservation and storage. Vet Res Commun 33 Suppl 1, 15-23.

Dalgaard, P. (1995) Qualitative and quantitative characterization of spoilage bacteria from packed fish. Int J Food Microbiol 26, 319-333.

Daniel, C., Sebbane, F., Poiret, S., Goudercourt, D., Dewulf, J., Mullet, C., Simonet, M. and Pot, B. (2009)Protection against Yersinia pseudotuberculosis infection conferred by a Lactococcus lactis mucosal delivery vector secreting LcrV. Vaccine 27, 1141-1144.

This article is protected by copyright. All rights reserved. 
Delhalle, L., Korsak, N., Taminiau, B., Nezer, C., Burteau, S., Delcenserie, V., Poullet, J., Daube, G. (2016) Exploring the bacterial, diversity of Belgian steak tartare using metagenetics and quantitative real-time PCR analysis. J of Food Prot 10, 220-229

Denis, C., La Carbona, S., Hanin, A., Chaillou, S., Zagorec, M. and Champomier-Vergès, M.C. (2014) Spoilage and biopreservation of veal meat. Poster at the FoodMicro conference, Nantes. France.http://www.actalia.eu/wp-content/uploads/2014/09/Poster-Ecobiopro.pdf

EFSA (2011)Scientific Opinion on the safety and efficacy of Lactococcus lactis (NCIMB 30160) as a silage additive for all species.

http://www.efsa.europa.eu/sites/default/files/scientific_output/files/main_documents/2366.pdf . (accessed 23.10.15).

Eldar, A., Ghittino, C., Asanta, L., Bozzetta, E., Goria, M., Prearo, M. and Bercovier, H. (1996) Enterococcus seriolicida is a junior synonym of Lactococcus garvieae, a causative agent of septicemia and meningoencephalitis in fish. Curr Microbiol 32, 85-88.

El-Ziney, M.G., van den Tempel, T., Debevere, J. and Jakobsen, M. (1999) Application of reuterin produced by Lactobacillus reuteri 12002 for meat decontamination and preservation. $J$ of Food Prot 62, 257-261.

Fall, P.-A.(2011) Études des interactions entre la bactérie bioprotectrice Lactococcus piscium et Brochothrix thermosphacta et Listeria monocytogenes dans la crevette tropicale. Université de Nantes. http://archimer.ifremer.fr/doc/00050/16164/

Fall, P.A., Leroi, F., Cardinal, M., Chevalier, F. and Pilet, M.F. (2010a)Inhibition of Brochothrix thermosphacta and sensory improvement of tropical peeled cooked shrimp by Lactococcus piscium CNCM I-4031. Lett App Microbiol 50, 357-361.

Fall, P.A., Leroi, F., Chevalier, F., Guerin, C. and Pilet, M.F. (2010b)Protective Effect of a NonBacteriocinogenic Lactococcus piscium CNCM I-4031 Strain Against Listeria monocytogenes in Sterilized Tropical Cooked Peeled Shrimp. J Aquat Food Prod Technol 19, 84-92.

Fall, P.A., Pilet, M.F., Leduc, F., Cardinal, M., Duflos, G., Guérin, C., Joffraud, J.J. and Leroi, F. (2012) Sensory and physicochemical evolution of tropical cooked peeled shrimp inoculated

This article is protected by copyright. All rights reserved. 
by Brochothrix thermosphacta and Lactococcus piscium CNCM I-4031 during storage at $8^{\circ}$ C. Int J Food Microbiol 152, 82-90.

Ferrocino, I., Greppi,A., La Storia, A., Rantsiou, K., Ercolini, D., Cocolin, L. (2015) Impact of nisinactivated packaging on microbiota of beef burgers, during storage. App Environ Microbiol 82, 549-559

Gambarin, P., Magnabosco, C., Losio, M.N., Pavoni, E., Gattuso, A., Arcangeli, G. and Favretti, M. (2012)Listeria monocytogenes in ready-to-eat seafood and potential hazards for the consumers. Int J Food Microbiol 2012, 497635, 10 pages.

Garnier, M., Matamoros, S., Chevret, D., Pilet, M.F., Leroi, F. and Tresse, O. (2010)Adaptation to cold and proteomic responses of the psychrotrophic biopreservative Lactococcus piscium strain CNCM I-4031. App Environ Microbiol 76, 8011-8018.

Ghanbari, M., Jami, M., Domig, K.J. and Kneifel, W. (2013) Seafood biopreservation by lactic acid bacteria - A review. LWT - Food Sci Technol54, 315-324.

Graumann, P.L. and Marahiel, M.A. (1998) A superfamily of proteins that contain the cold-shock domain.Trends Biochem Sci 23, 286-290.

Gustavsson, J., Cederberg, C., Sonesson, U., van Otterdijk, R. and Meybeck, A. (2011) Global food losses and food waste - Extent, causes and prevention (Global food losses and food waste Study conducted for the International Congress: SAVE FOOD). Germany. http://www.fao.org/docrep/014/mb060e/mb060e.pdf. (accessed 11/03/2015)

Hamasaki, Y., Ayaki, M., Fuchu, H., Sugiyama, M. and Morita, H. (2003)Behavior of psychrotrophic lactic acid bacteria isolated from spoiling cooked meat products. App Environ Microbiol 69, $3668-3671$.

Hibbing, M.E., Fuqua, C., Parsek, M.R. and Peterson, S.B. (2010) Bacterial competition: surviving and thriving in the microbial jungle. Nat Rev Microbiol 8, 15-25.

https://www.patricbrc.org. Lactococcus chungangensis CAU 28 = DSM 22330::Genome Overview. https://www.patricbrc.org/portal/portal/patric/Genome?cType=genome\&cId=1122154.4 (accessed 10.23.15).

This article is protected by copyright. All rights reserved. 
http://www.ebi.ac.uk/ena. European Nucleotide Archive. http://www.ebi.ac.uk/ena (accessed 12.24.15).

http://www.ncbi.nlm.nih.gov, 2015. Lactococcus fujiensis JCM 16395 DNA, contig: JCM16395.contig00001, whole genome shotgun sequence. http://www.ncbi.nlm.nih.gov/nuccore/NZ_BBAL01000001.1 (accessed 11.2.15).

Jääskeläinen, E., Vesterinen, S., Parshintsev, J., Johansson, P., Riekkola, M.L. and Björkroth, J. (2015) Production of buttery-odor compounds and transcriptome response in Leuconostoc gelidum subsp. gasicomitatum LMG18811T during growth on various carbon sources. App Environ Microbiol 81, 1902-1908.

Jääskeläinen, E., Hultman, J., Parshintsev, J., Riekkola, M.L. and Björkroth, J. (2016) Development of spoilage bacterial community and volatile compounds in chilled beef under vaccum or high oxygen atmospheres. Int J Food Microbiol 223, 25-32.

Jiang, Y., Gao, F., Xu, X.L., Su, Y., Ye, K.P. and Zhou, G.H. (2010) Changes in the bacterial communities of vacuum-packaged pork during chilled storage analyzed by PCR-DGGE. Meat Sci 86, 889-895.

Juillard, V., Foucaud, C., Flambard, B., Furlan, S., Bellengier, P. and Richard, J. (1998) Interactions entre bactéries lactiques mésophiles dans le lait : Rôle des facteurs nutritionnels. Le Lait 78, 91-97.

Kelly, W.J., Ward, L.J.H. and Leahy, S.C. (2010) Chromosomal diversity in Lactococcus lactis and the origin of dairy starter cultures. Genome Biol Evol 2, 729-744.

Kesmen, Z., Yetiman, A.E., Gulluce, A., Kacmaz, N., Sagdic, O., Cetin, B., Adiguzel, A., Sahin, F. and Yetim, H. (2012) Combination of culture-dependent and culture-independent molecular methods for the determination of lactic microbiota in sucuk. Int J Food Microbiol 153, 428435.

Kubota, H., Tsuji, H., Matsuda, K., Kurakawa, T., Asahara, T. and Nomoto, K. (2010) Detection of human intestinal catalase-negative, Gram-positive cocci by rRNA-targeted reverse transcription-PCR.App Environ Microbiol 76, 5440-5451.

This article is protected by copyright. All rights reserved. 
Lacroix, C. (2010) Protective Cultures, Antimicrobial metabolites and aacteriophages for food and beverage biopreservation. Cambridge:Woodhead Publishing Limited (Elsevier)

Laursen, B.G., Leisner, J.J. and Dalgaard, P.(2006)Carnobacterium species: effect of metabolic activity and interaction with Brochothrix thermosphacta on sensory characteristics of modified atmosphere packed shrimp. Journal of Agricultural and Food Chemistry 54, 36043611.

Leroi, F., Cornet, J., Chevalier, F., Cardinal, M., Coeuret, G., Chaillou, S. and Joffraud, J.J.(2015) Selection of bioprotective cultures for preventing cold-smoked salmon spoilage. Int J Food Microbiol 20,79-87.

Leroi, F., Fall, P.A., Pilet, M.F., Chevalier, F. and Baron, R. (2012)Influence of temperature, pH and $\mathrm{NaCl}$ concentration on the maximal growth rate of Brochothrix thermosphacta and a bioprotective bacteria Lactococcus piscium CNCM I-4031. Food Microbiol 31, 222-228.

Lomonaco, S., Nucera, D. and Filipello, V. (2015)The evolution and epidemiology of Listeria monocytogenes in Europe and the United States. Infect Genet Evol 35, 172-183.

Lupien, J.R. (1997) Agriculture food and nutrition for Africa - A resource book for teachers of agriculture. Rome: FAO. http://www.fao.org/docrep/w0078e/w0078e00.HTM (accessed 10.23.15).

Macé, S., Cornet, J., Chevalier, F., Cardinal, M., Pilet, M.-F., Dousset, X. and Joffraud, J.J. (2012) Characterisation of the spoilage microbiota in raw salmon (Salmo salar) steaks stored under vacuum or modified atmosphere packaging combining conventional methods and PCRTTGE. Food Microbiol 30,164-167.

Macé, S., Joffraud, J.-J., Cardinal, M., Malcheva, M., Cornet, J., Lalanne, V., Chevalier, F., Sérot, T., Pilet, M.F. and Dousset, X. (2013) Evaluation of the spoilage potential of bacteria isolated from spoiled raw salmon (Salmo salar) fillets stored under modified atmosphere packaging. Int J Food Microbiol 160, 227-238.

Makarova, K., Slesarev, A., Wolf, Y., Sorokin, A., Mirkin, B., Koonin, E., Pavlov, A., Pavlova, N., Karamychev, V., Polouchine, N., Shakhova, V., Grigoriev, I., Lou, Y., Rohksar, D., Lucas, S., Huang, K., Goodstein, D.M., Hawkins, T., Plengvidhya, V., Welker, D., Hughes, J., Goh, 
Y., Benson, A., Baldwin, K., Lee, J.-H., Díaz-Muñiz, I., Dosti, B., Smeianov, V., Wechter, W., Barabote, R., Lorca, G., Altermann, E., Barrangou, R., Ganesan, B., Xie, Y., Rawsthorne, H., Tamir, D., Parker, C., Breidt, F., Broadbent, J., Hutkins, R., O’Sullivan, D., Steele, J., Unlu, G., Saier, M., Klaenhammer, T., Richardson, P., Kozyavkin, S., Weimer, B. and Mills, D. (2006) Comparative genomics of the lactic acid bacteria. Proc Natl Acad Sci U S A 103, 15611-15616.

Marché, L., Saraoui, T., Remenant, B., Zagorec, M., Prévost, H., Leroi, F. and Pilet, M.F. (2014)Lactococcus piscium whole genome sequencing to investigate inhibiting behaviour in food ecosystem. Poster at the FoodMicro conference, Nantes. France. https://w3.ifremer.fr/archimer/doc/00241/35201/33705.pdf

Matamoros, S. (2008) Caractérisation de bactéries lactiques psychrotrophes en vue de leur utilisation dans la biopréservation des aliments. Étude physiologique et moléculaire des mécanismes d'adaptation au froid. Université de Nantes. http://archimer.ifremer.fr/doc/00050/16148/

Matamoros, S., Pilet, M.F., Gigout, F., Prévost, H. and Leroi, F.(2009a) Selection and evaluation of seafood-borne psychrotrophic lactic acid bacteria as inhibitors of pathogenic and spoilage bacteria. Food Microbiol 26, 638-644.

Matamoros, S., Leroi, F., Cardinal, M., Gigout, F., Kasbi Chadli, F., Cornet, J., Prévost, H. and Pilet, M.F. (2009b) Psychrotrophic lactic acid bacteria used to improve the safety and quality of vacuum-packaged cooked and peeled tropical shrimp and cold-smoked salmon. J Food Prot 72, 365-374.

Meslier, V., Loux, V. and Renault, P. (2012) Genome sequence of Lactococcus raffinolactis strain 4877, isolated from natural dairy starter culture.J Bacteriol 194, 6364-6364.

Meucci, A., Zago, M., Rossetti, L., Fornasari, M.E., Bonvini, B., Tidona, F., Povolo, M., Contarini, G., Carminati, D. and Giraffa, G. (2015)Lactococcus hircilactis sp. nov., Lactococcus laudensis sp. nov., isolated from milk. Int J Syst Evol Microbiol 65, 2091-2096.

Michel, C., Pelletier, C., Boussaha, M., Douet, D.-G., Lautraite, A. and Tailliez, P. (2007) Diversity of lactic acid bacteria associated with fish and the fish farm environment, established by amplified rRNA gene restriction analysis. App Environ Microbiol 73, 2947-2955.

This article is protected by copyright. All rights reserved. 
Michel, V., Lehoux, I., Depret, G., Anglade, P., Labadie, J. and Hebraud, M. (1997)The cold shock response of the psychrotrophic bacterium Pseudomonas fragi involves four low-molecularmass nucleic acid-binding proteins. J Bacteriol 179, 7331-7342.

Morita, H., Toh, H., Oshima, K., Yoshizaki, M., Kawanishi, M., Nakaya, K., Suzuki, T., Miyauchi, E., Ishii, Y., Tanabe, S., Murakami, M. and Hattori, M. (2011)Complete genome sequence and comparative analysis of the fish pathogen Lactococcus garvieae. PLoS ONE 6(8).

Morse, R.P., Nikolakakis, K.C., Willett, J.L.E., Gerrick, E., Low, D.A., Hayes, C.S., Goulding, C.W. (2012) Structural basis of toxicity and immunity in contact-dependent growth inhibition (CDI) systems. Microbiology 109, 21480-21485.

Nilsson, L., Hansen, T. b., Garrido, P., Buchrieser, C., Glaser, P., Knøchel, S., Gram, L. and Gravesen, A. (2005). Growth inhibition of Listeria monocytogenes by a nonbacteriocinogenic Carnobacterium piscicola. J App Microbiol 98, 172-183.

Odamaki, T., Yonezawa, S., Kitahara, M., Sugahara, Y., Xiao, J.Z., Yaeshima, T., Iwatsuki, K. and Ohkuma, M.(2011)Novel multiplex polymerase chain reaction primer set for identification of Lactococcus species. Lett App Microbiol 52, 491-496.

Passerini, D., Beltramo, C., Coddeville, M., Quentin, Y., Ritzenthaler, P., Daveran-Mingot, M.-L. and Le Bourgeois, P. (2010) Genes but not genomes reveal bacterial domestication of Lactococcus lactis. PLoS ONE5 (12).

Pothakos, V., Snauwaert, C., De Vos, P., Huys, G. and Devlieghere, F. (2014a) Monitoring psychrotrophic lactic acid bacteria contamination in a ready-to-eat vegetable salad production environment. Int J Food Microbiol 185, 7-16.

Pothakos, V., Snauwaert, C., De Vos, P., Huys, G. and Devlieghere, F. (2014b) Psychrotrophic members of Leuconostoc gasicomitatum, Leuconostoc gelidum and Lactococcus piscium dominate at the end of shelf-life in packaged and chilled-stored food products in Belgium. Food Microbiol 39, 61-67.

Pothakos, V., Nyambi, C., Zhang, B.-Y., Papastergiadis, A., De Meulenaer, B. and Devlieghere, F. (2014c) Spoilage potential of psychrotrophic lactic acid bacteria (LAB) species: Leuconostoc

This article is protected by copyright. All rights reserved. 
gelidum subsp. gasicomitatum and Lactococcus piscium, on sweet bell pepper (SBP) simulation medium under different gas compositions.Int J Food Microbiol 178, 120-129.

Rahkila, R., Nieminen, T., Johansson, P., Säde, E. and Björkroth, J. (2012) Characterization and evaluation of the spoilage potential of Lactococcus piscium isolates from modified atmosphere packaged meat. Int J Food Microbiol 156, 50-59.

Ross, R.P., Morgan, S. and Hill, C. (2002) Preservation and fermentation: past, present and future. Int J Food Microbiol 79, 3-16.

Rouse, S. and van Sinderen, D. (2008) Bioprotective Potential of Lactic Acid Bacteria in Malting and Brewing. J Food Prot 71, 1724-1733.

Russo, F., Ercolini, D., Mauriello, G. and Villani, F.(2006) Behaviour of Brochothrix thermosphacta in presence of other meat spoilage microbial groups. Food Microbiol 23, 797-802.

Sakala, R.M., Hayashidani, H., Kato, Y., Hirata, T., Makino, Y., Fukushima, A., Yamada, T., Kaneuchi, C. and Ogawa, M. (2002a) Change in the composition of the microflora on vacuum-packaged beef during chiller storage. Int J Food Microbiol 74, 87-99.

Sakala, R.M., Hayashidani, H., Kato, Y., Kaneuchi, C. and Ogawa, M. (2002b) Isolation and characterization of Lactococcus piscium strains from vacuum-packaged refrigerated beef. $J$ App Microbiol 92, 173-179.

Samarzija, D., Antunac, N. and Havranek, J.-L. (2001) Taxonomy, physiology and growth of Lactococcus lactis: a review. Mljekarstvo 51, 35-48.

Saraoui, T., Fall, P. A., Leroi, F., Antignac, J.-P., Chéreau, S. and Pilet, M. F. (2016) Inhibition mechanism of Listeria monocytogenes by a bioprotective bacteria Lactococcus piscium CNCM I-4031. Food Microbiol 53, 70-78.

Sarika, A.R., Lipton, A.P., Aishwarya, M.S. and Dhivya, R.S. (2012) Isolation of a Bacteriocinproducing Lactococcus lactis and application of Its bacteriocin to manage spoilage bacteria in high-value marine fish under different storage temperatures. AppBiochem Biotechnol 167, 1280-1289.

This article is protected by copyright. All rights reserved. 
Schleifer, K.H., Kraus, J., Dvorak, C., Kilpper-Bälz, R., Collins, M.D. and Fischer, W.(1985)Transfer of Streptococcus lactis and related Streptococci to the genus Lactococcus gen. nov. Syst AppMicrobiol 6, 183-195.-

Stiles, M.E.(1996) Biopreservation by lactic acid bacteria. Antonie van Leeuwenhoek 70, 331-345.

Stiles, M.E.and Holzapfel, W.H. (1997) Lactic acid bacteria of foods and their current taxonomy. Int J Food Microbiol 36, 1-29.

Tsakalidou, E. and Papadimitriou, K. (2011) Stress Responses of Lactic Acid Bacteria. London: Springer Science \& Business Media.

Vendrell, D., Balcázar, J.L., Ruiz-Zarzuela, I., de Blas, I., Gironés, O. and Múzquiz, J.L. (2006) Lactococcus garvieae in fish: A review. Comp Immunol Microbiol Infect Dis 29, 177-198.

Vihavainen, E., Lundström, H.-S., Susiluoto, T., Koort, J., Paulin, L., Auvinen, P. and Björkroth, K.J. (2007) Role of broiler carcasses and processing plant air in contamination of modifiedatmosphere-packaged broiler products with psychrotrophic lactic acid bacteria. App Environ Microbiol 73, 1136-1145.

Von Wright, A.(2012) Genus Lactococcus, InLactic Acid Bacteria: Microbiological and Functional Aspects ed. Lahtinen, S., Ouwehand, A.-C., Salminen,S. andvon Wrigh, A.,pp. 63-76. Boca Raton: CRC Press.

Williams, A.M., Fryer, J.L., Collins and M.D. (1990) Lactococcus piscium sp. nov. a new Lactococcus species from salmonid fish. FEMS Microbiol Lett 68, 109-113.

Wong, H.-C. and Chen, Y.-L. (1988) Effects of Lactic Acid Bacteria and Organic Acids on Growth and Germination of Bacillus cereus. App Environ Microbiol 54, 2179-2184.

This article is protected by copyright. All rights reserved. 
Figure 1

Phylogenetic relationship of species and subspecies of the genus Lactococcus. The 16S rRNA gene sequences of the eleven different Lactococcus species, including the four subspecies of L. lactis and two genome sequenced L. piscium ( $\bullet$, were retrieved from GenBank (http://www.ncbi.nlm.nih.gov). After the trimming of the gaps and missing data, a total of 1330 positions were aligned using clustal W software. The construction of phylogenetic trees was performed with MEGA 6 Toolbar using the neighbor-joining method with bootstrap of 1000 replicates. Lactobacillus curvatus was used as an outgroup species.

Figure 2: Scanning Electron Microscopy of Lactococcus piscium CNCM I-4031 after $24 \mathrm{~h}$ of culture in Elliker medium (x 30000).

This article is protected by copyright. All rights reserved. 
Table 1: Food sources of Lactococcus piscium and its sensory effect, when inoculated into fish and meat product.

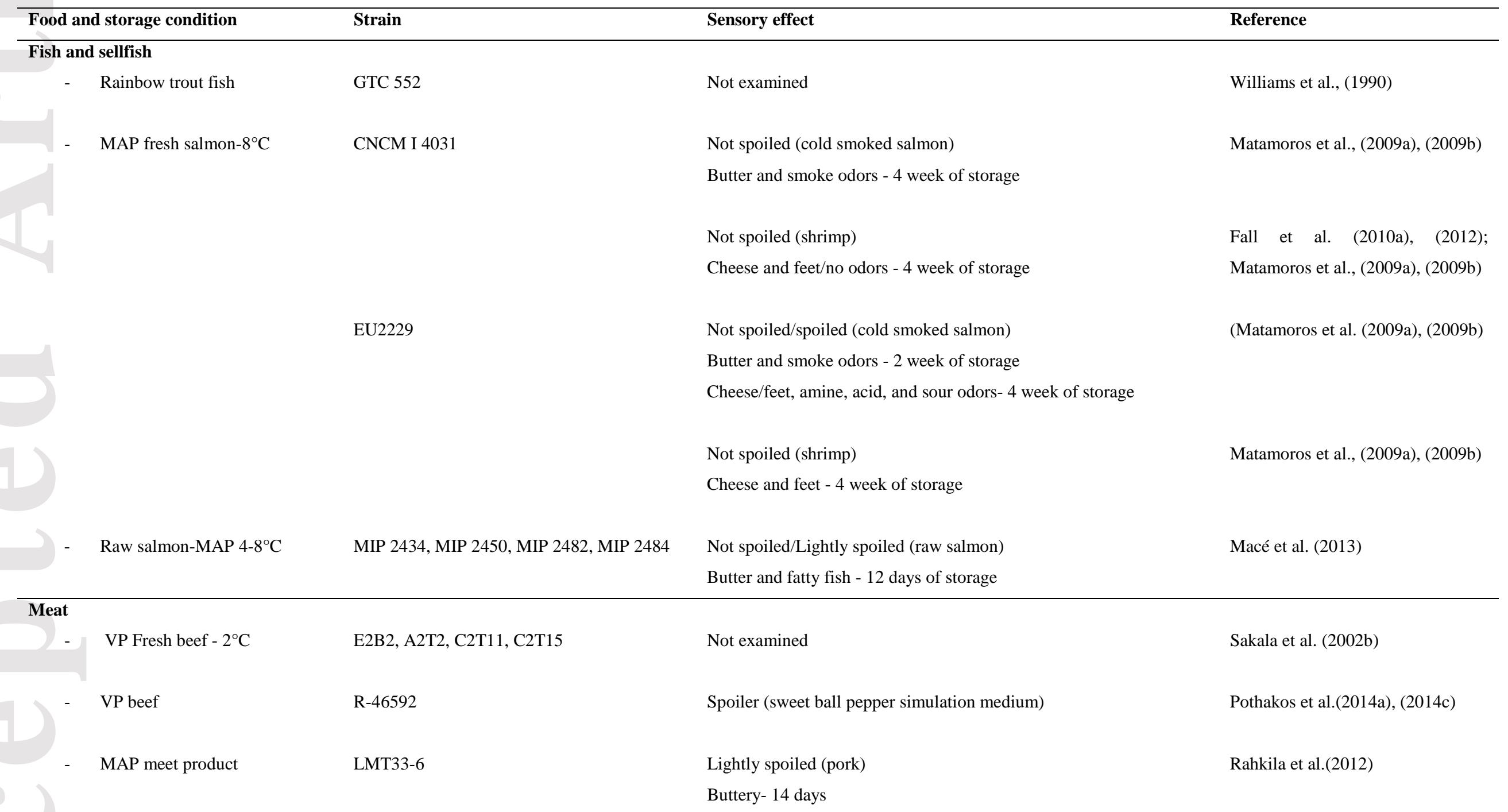

This article is protected by copyright. All rights reserved. 
Lightly spoiled (pork)

Sour - 16 days

VP pork $-4^{\circ} \mathrm{C}$

EU621998

R-46738

MKFS47
Not examined

Lightly spoiler (sweet ball pepper simulation medium)

Spoiled (pork)

Buttery
Rahkila et al. (2012)

Jiang et al., (2010)

Pothakos et al.(2014a), (2014c)

Andreevskaya et al. (2015)

\section{Vegetable}

- Sweet bell pepper salad (air)

R-46976

Lightly spoiler (sweet ball pepper simulation medium)

Pothakos et al.(2014b)

This article is protected by copyright. All rights reserved. 
Table 2: Genome overview of some Lactococcus strains genome sequenced including the two L. piscium strains genome sequenced.

\begin{tabular}{|c|c|c|c|c|c|c|c|c|}
\hline 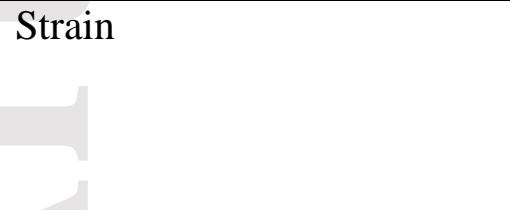 & $\begin{array}{c}\text { Genome deposit } \\
\text { number (GenBank) }\end{array}$ & $\begin{array}{l}\text { Genome } \\
\text { size (kbp) }\end{array}$ & $\mathrm{GC} \%$ & Plasmid(s) & CDS & $\begin{array}{c}\text { Ribosomal } \\
\text { RNA } \\
\text { operons }\end{array}$ & tRNA & Reference \\
\hline $\begin{array}{l}\text { Lactococcus piscium CNCM } \\
\text { I-4031 }\end{array}$ & In progress & 2257 & 39 & 1 & 2239 & 4 & 55 & Marché et al. (2014) \\
\hline $\begin{array}{l}\text { Lactococcus piscium } \\
\text { MKFS47 }\end{array}$ & $\begin{array}{l}\text { LN774769- } \\
\text { LN77477 }\end{array}$ & 2394 & 38.79 & 2 & 2476 & 4 & 56 & Andreevskaya et al., (2015) \\
\hline $\begin{array}{l}\text { Lactococcus lactis subsp. } \\
\text { lactis IL1403 }\end{array}$ & AE005176 & 2365 & 35.4 & 0 & 2310 & 6 & 62 & Bolotin et al. (2001) \\
\hline $\begin{array}{l}\text { Lactococcus lactis subsp. } \\
\text { cremoris SK11 }\end{array}$ & CP000430 & 2641 & 35.8 & 5 & 2509 & 6 & 62 & Makarova et al., (2006) \\
\hline $\begin{array}{l}\text { Lactococcus garvieae } \\
\text { ATCC } 49156\end{array}$ & AP009332 & 1950 & 38.8 & 0 & 1947 & 5 & 62 & Morita et al., (2011) \\
\hline $\begin{array}{l}\text { Lactococcus raffinolactis } \\
4877\end{array}$ & CALL00000000 & 2280 & 38.7 & 0 & 2418 & - & 48 & Meslier et al. (2012) \\
\hline $\begin{array}{l}\text { Lactococcus fujiensis JCM } \\
16395\end{array}$ & BBAL00000000.1 & 2088 & 36.9 & nd & 2252 & 4 & 47 & http://www.ncbi.nlm.nih.gov \\
\hline $\begin{array}{l}\text { Lactococcus chungangensis } \\
\text { CAU } 28\end{array}$ & - & 2243 & 40 & nd & 2194 & 3 & 47 & $\begin{array}{l}\text { Cho et al. (2008); } \\
\text { https://www.patricbrc.org }\end{array}$ \\
\hline
\end{tabular}

This article is protected by copyright. All rights reserved. 
Table 3: Antimicrobial activity of Lactococcus piscium strains against spoilage and pathogenic bacteria relevant in food

\begin{tabular}{|c|c|c|c|c|}
\hline Methods & L. piscium strains & Target strain & $\begin{array}{l}\text { Growth } \\
\text { inhibition }\end{array}$ & Reference \\
\hline \multirow[t]{4}{*}{ Agar spot assay with L. piscium colony } & EU2229 & $\begin{array}{l}\text { Staphylococcus aureus, Brochothrix thermosphacta, Psychrobacter } \mathrm{sp} . \\
\text { Pseudomonas sp., Serratia liquefaciens, Photobacterium phosphoreum, } \\
\text { Shewanella putrefaciens, Clostridium sporogenes, Lactobacillus farciminis and } \\
\text { Listeria monocytogenes }\end{array}$ & Inhibited & Matamoros et al. (2009a) \\
\hline & & $\begin{array}{l}\text { Bacillus subtilis, Staphylococcus xylosus, Escherichia coli, Salmonella } \\
\text { enterica }\end{array}$ & Not inhibited & Matamoros et al. (2009a) \\
\hline & CNCM I-4031 & $\begin{array}{l}\text { Brochothrix thermosphacta, Carnobacterium alterfunditum, C. divergens, C. } \\
\text { maltaromaticum, Clostridium sporogenes, Escherichia coli, Lactobacillus } \\
\text { farciminis, Listeria monocytogenes, Photobacterium phosphoreum, } \\
\text { Psychrobacter sp., Pseudomonas sp., Salmonella enterica serovar } \\
\text { Typhimirium, Serratia liquefaciens, Serratia sp., Shewanella putrefaciens, } \\
\text { Staphylococcus aureus, Vagococcus fluvialis and Vagococcus carniphilus }\end{array}$ & Inhibited & $\begin{array}{l}\text { Fall et al. (2010a); } \\
\text { Matamoros et al. (2009a) }\end{array}$ \\
\hline & & Bacillus subtilis, Staphylococcus xylosus, Vibriosp. & Not Inhibited & $\begin{array}{l}\text { Fall et al. (2010a); } \\
\text { Matamoros et al. (2009a) }\end{array}$ \\
\hline $\begin{array}{l}\text { Agar spot assay with } L . \text { piscium } \\
\text { supernatant (MSMA medium) }\end{array}$ & CNCM I-4031 & Listeria monocytogenes & Not Inhibited & $\begin{array}{l}\text { Fall et al. (2010a); Saraoui } \\
\text { et al. (2016) }\end{array}$ \\
\hline Co-culture on MSMA medium & CNCM I-4031 & Listeria monocytogenes & Inhibited & Saraoui et al. (2016) \\
\hline Peeled and cooked shrimp & CNCM I-4031 & $\begin{array}{l}\text { Brochothrix thermosphacta } \\
\text { Listeria monocytogenes }\end{array}$ & $\begin{array}{l}\text { Inhibited } \\
\text { Inhibited }\end{array}$ & $\begin{array}{l}\text { Fall et al. (2010a) } \\
\text { Fall et al. (2010b) }\end{array}$ \\
\hline Cold smoked salmon & CNCM I-4031 & $\begin{array}{l}\text { Brochotrix. thermosphacta, Serratia proteamaculans } \\
\text { Photobacterium phosphoreum }\end{array}$ & $\begin{array}{l}\text { Inhibited } \\
\text { Not inhibited }\end{array}$ & $\begin{array}{l}\text { Leroi et al. (2015) } \\
\text { Leroi et al. (2015) }\end{array}$ \\
\hline
\end{tabular}

This article is protected by copyright. All rights reserved. 


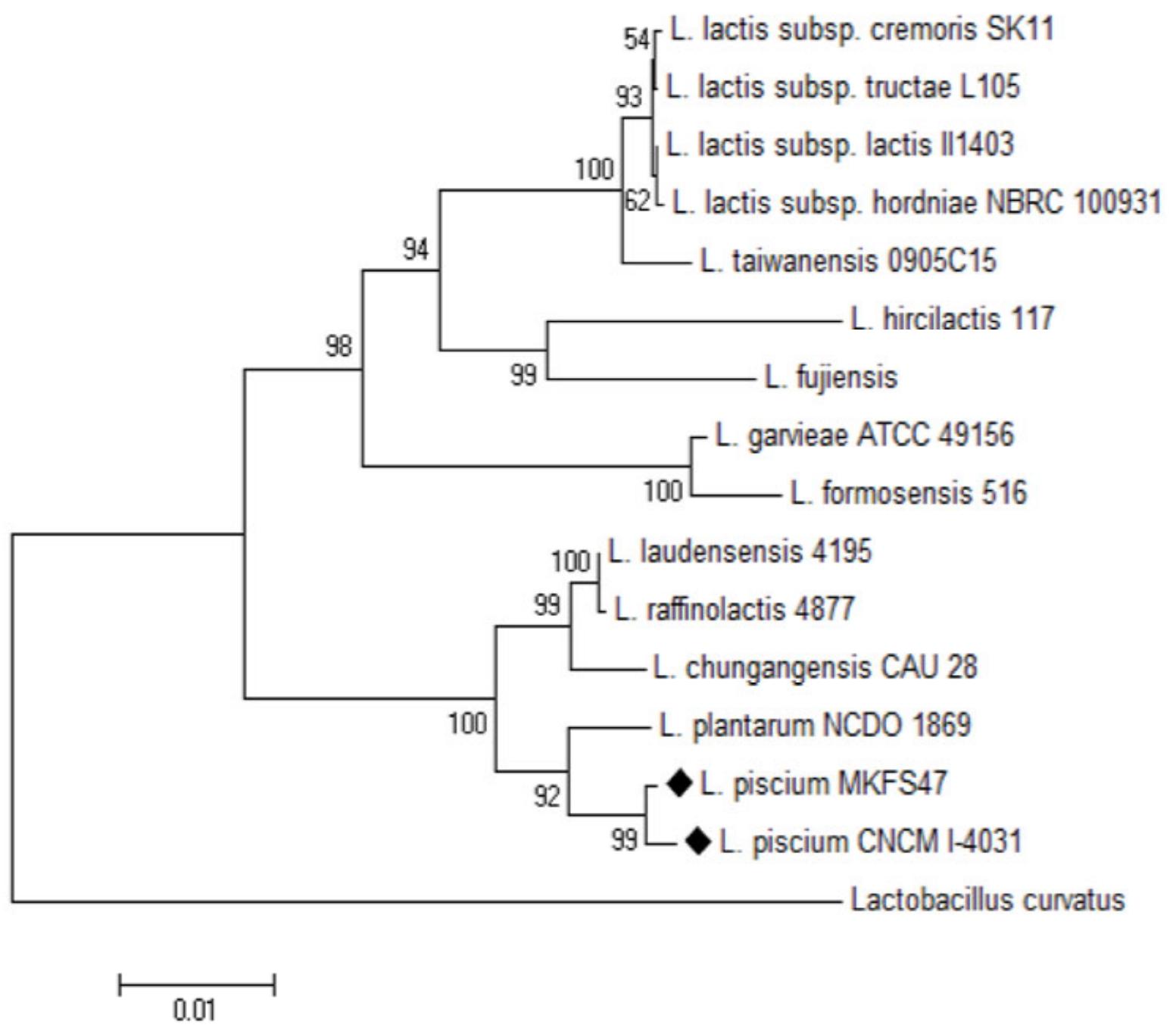

This article is protected by copyright. All rights reserved. 

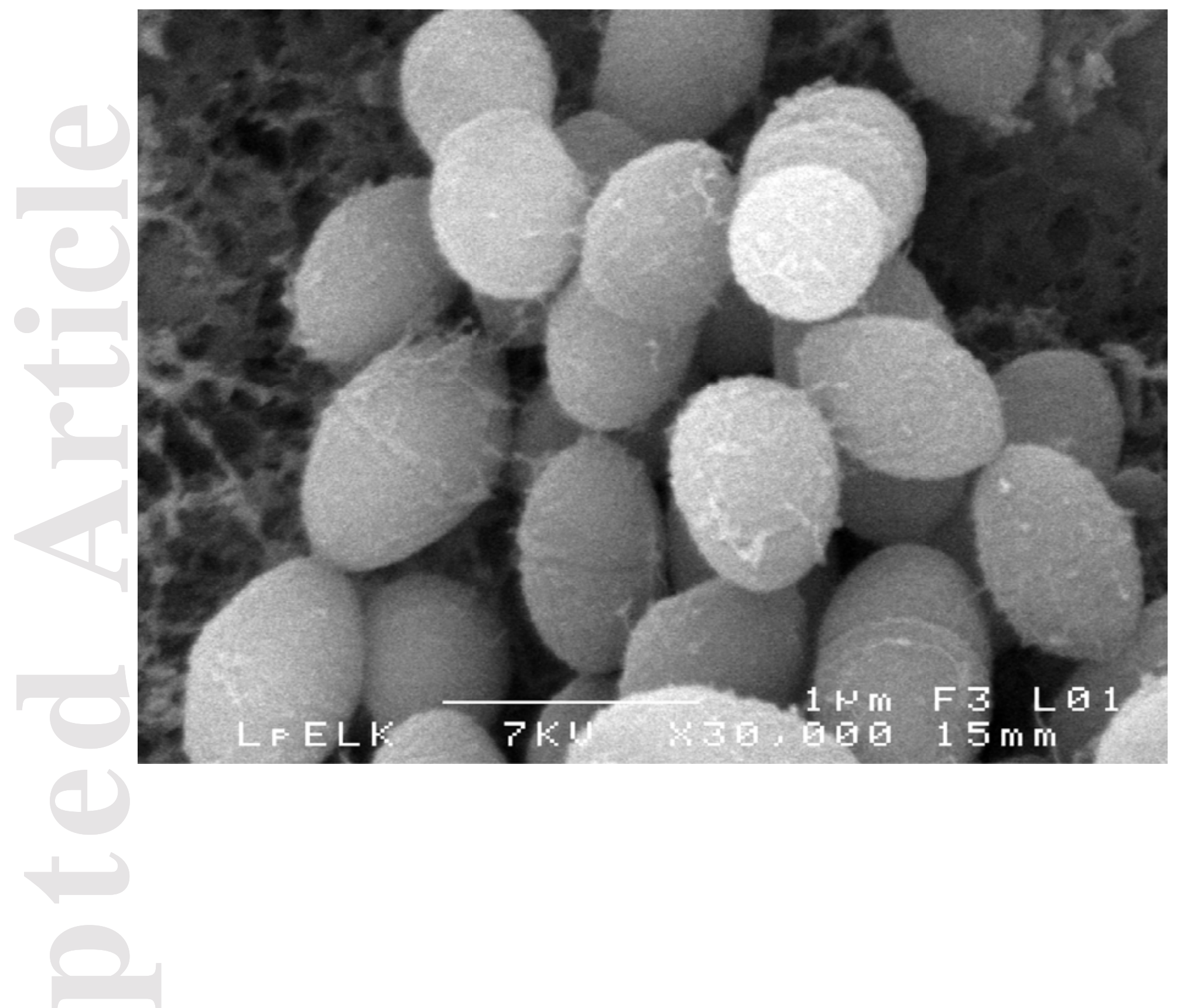

This article is protected by copyright. All rights reserved. 